\section{CHALLENGER SOCIETY}

\section{Newcustle Meeting}

from a Correspondent

THE opening theme of the joint meeting of the Challenger Society and representatives of marine laboratories, held in the University of Newcastle upon Tyne on March 27 and 28, was the gross estuarine pollution of the north-east coast of England. It is an unhappy commentary that a similar theme characterized a meeting of the Challenger Society at the Dove Marine Laboratory exactly fifty years ago.

Dr J. S. Gray (University of Leeds) has been monitoring Seal Sands in the Tees estuary, an area once indeed sandy and harbouring seals, but now a mudflat. Nevertheless, in spite of heavy industrial pollution the meiofaunal density of the intertidal sediment here averages 2.5 million organisms per square metre. Dr Gray has found that the species diversity of the annelids of the area is reduced in certain limited stretches; it seems likely that pollution here may reach a peak, yet he is not satisfied that this reduction in diversity can be categorically related to pollution.

Dr A. James (University of Newcastle upon Tyne) described the effects of directing polluting discharges into the Tyne estuary, chiefly in terms of the dissolved oxygen regime, but some mention was also made of intestinal bacteria and nutrient budgets. He showed the results of a one-dimensional model which has been developed to help predict future levels of organic matter, bacteria, nutrients and oxygen.

Dr P. G. Moore (University Marine Biological Station, Millport), taking a more generalized view of environmental quality in the sea, also considered the possibility of using ecological diversity values as indices of pollution. He looked particularly at diversity indices biased towards the equitability component. $\mathrm{He}$ has found that although there are problems concerned with varying key species and with the choice of animal size and taxa, the principal difficulty lies not in the measurement of diversity but in its interpretation, so that its use as an indicator of pollution, while possible, requires caution.

Dr R. Johnston (DAFS Marine Laboratory, Aberdeen) returned to specific cases and outlined the problems involved in predicting the effects of a proposed new pulp mill on the chemistry of the waters of two Scottish sea lochs, Linnhe and Eil. A decision whether or not to permit a discharge from the mill into the lochs was required in 1961 although the actual discharge would not begin until 1966. The complexities of the hydrographic situation were unravelled and future changes in dissolved oxygen and bio- logical oxygen demand (BOD) were estimated and found acceptable. Once the mill was working subsequent routine observation enabled the minor reduction in dissolved oxygen and the minor increase in $\mathrm{BOD}$ in the water to be correlated with the BOD and suspended solids input of the mill.

The plankton session was opened by Dr F. Evans (University of Newcastle upon Tyne) who spoke of the long history of plankton sampling in Northumberland coastal waters, extending as far back as 1860 although in a much broken series. The Northumberland plankton does not, he said, derive at all from populations to the south of the county but consists of species constantly found locally, supplemented intermittently by immigrants from the north. This accords with the predominantly southward flow of wind-induced currents close inshore, but it is a matter for remark that species well known only $\mathbf{5 0}$ miles to the south are not brought northwards into the region during times of contrary winds and accompanying northerly flow.

A "Challenger" plankton session would seem incomplete without a contribution from Edinburgh, and the demand was met by Dr R. Williams

\section{Exiruction of Gonadotrophin Receptors}

RECEPTORS can be defined as components of a tissue which specifically react with a drug or hormone and which are essential for the expression of the biological activity of the compound. In endocrinology, interest in receptors was renewed about 1960 when it was postulated that specific proteins in tissues of the reproductive tract interact with the sex hormones and are responsible for their uptake by the tissues. Presence of the receptors also explained the specificity of the action of the sex hormones on reproductive tissues. The sex hormones, however, are known to affect metabolic reactions in almost all tissues and presumably therefore proteins which interact with the hormones and which could be called receptors should be present in other tissues as well as those of the reproductive tract. The meaning of "receptor" is becoming very diffuse and a clearer definition of the word is necessary. Receptors which interact with polypeptide hormones have also been shown to be present in tissues; these receptors seem to be membranebound and hence their isolation presents difficulties.

In next Wednesday's Nature New Biology (April 25) Dufau and Catt describe a procedure for the extraction of gonadotrophin receptors from the interstitial cells of rat testes. After subcellular particles were isolated by centrifugation, they were dispersed in 'Triton'buffer solution. After extensive high-
(Institute for Marine Environmental Research) who gave an account of the extensive sampling programme at Ocean Weather Station "India". The equipment used includes sophisticated sensors of the physical environment combined with a plankton net which incorporates the Hardy-Longhurst cod-end for controlled depth sampling.

Dr M. Sheader (University of Newcastle upon Tyne) dealt with a planktonic group -the hyperiid amphipods of the North Sea-which was previously inadequately known. Of the three North Sea genera, Hyperia, Hyperoche and Parathemisto, he dwelt more especially on the last. His taxonomic studies show conclusively that the large, oceanic $P$. gaudichaudi and the smaller, neritic $P$. gracilipes are in fact the same species ; furthermore, laboratory rearing of the young of both forms produces animals which are indistinguishable from each other provided environmental factors are equal.

The plankton session was concluded by Dr S. J. Lockwood (MAFF Fisheries Laboratory, Lowestoft) who reviewed the replenishment of the almost self-contained stock of plaice off the Yorkshire coast. He has found that eggs are spawned some 10 to 20 miles off the

speed centrifugation of the solution, gonadotrophin-binding activity was found only in the supernatant solution. Some loss of binding capacity occurred on solubilization, as the final solution had only about one third the binding capacity of the original particles and this was also associated with decrease in the association constant. Thus although all of the receptor may have been solubilized there well may have been a conformational change in the protein. The soluble receptors, however, still appeared to retain their hormonal specificity. Isolation of the receptors by this type of procedure should not only be a great help in their further characterization and investigation of the way in which they function but also enhance their usefulness in the development of methods for assay of gonadotrophins.

A second report, by Milin and Roy, is concerned with androgen-stimulated synthesis of globulin in rat liver. Hepatic tissue contains a "receptor" which on ultracentrifugation is different from the androgen-binding protein present in blood. Earlier studies showed the absence of this "receptor" in liver tissue of female and immature male rats and Milin and Roy used for their new studies a strain of rats which show no response to androgen because of a genetic defect. None of the "receptor" was detected by ultracentrifugation of the liver from these animals nor did they produce significant amounts of the globulin. 